\title{
Wind changes above warm Agulhas Current eddies
}

\author{
M. Rouault ${ }^{1,2}$, P. Verley ${ }^{3,6}$, and B. Backeberg ${ }^{2,4,5}$ \\ ${ }^{1}$ Department of Oceanography, Mare Institute, University of Cape Town, South Africa \\ ${ }^{2}$ Nansen-Tutu Center for Marine Environmental Research, University of Cape Town, South Africa \\ ${ }^{3}$ ICEMASA, IRD, Cape Town, South Africa \\ ${ }^{4}$ Nansen Environmental and Remote Sensing Centre, Bergen, Norway \\ ${ }^{5}$ NRE, CSIR, Stellenbosch, South Africa \\ ${ }^{6}$ IRD, UMR AMAP, Montpellier, France
}

Correspondence to: M. Rouault (mathieu.rouault@uct.ac.za)

Received: 8 September 2014 - Published in Ocean Sci. Discuss.: 21 October 2014

Revised: 7 March 2016 - Accepted: 9 March 2016 - Published: 5 April 2016

\begin{abstract}
Sea surface temperature (SST) estimated from the Advanced Microwave Scanning Radiometer E onboard the Aqua satellite and altimetry-derived sea level anomalies are used south of the Agulhas Current to identify warmcore mesoscale eddies presenting a distinct SST perturbation greater than to $1^{\circ} \mathrm{C}$ to the surrounding ocean. The analysis of twice daily instantaneous charts of equivalent stabilityneutral wind speed estimates from the SeaWinds scatterometer onboard the QuikScat satellite collocated with SST for six identified eddies shows stronger wind speed above the warm eddies than the surrounding water in all wind directions, if averaged over the lifespan of the eddies, as was found in previous studies. However, only half of the cases showed higher wind speeds above the eddies at the instantaneous scale; $20 \%$ of cases had incomplete data due to partial global coverage by the scatterometer for one path. For cases where the wind is stronger above warm eddies, there is no relationship between the increase in surface wind speed and the SST perturbation, but we do find a linear relationship between the decrease in wind speed from the centre to the border of the eddy downstream and the SST perturbation. SST perturbations range from 1 to $6^{\circ} \mathrm{C}$ for a mean eddy SST of $15.9^{\circ} \mathrm{C}$ and mean SST perturbation of $2.65^{\circ} \mathrm{C}$. The diameter of the eddies range from 100 to $250 \mathrm{~km}$. Mean background wind speed is about $12 \mathrm{~m} \mathrm{~s}^{-1}$ (mostly southwesterly to northwesterly) and ranging mainly from 4 to $16 \mathrm{~m} \mathrm{~s}^{-1}$. The mean wind increase is about $15 \%$, which corresponds to $1.8 \mathrm{~m} \mathrm{~s}^{-1}$. A wind speed increase of 4 to $7 \mathrm{~m} \mathrm{~s}^{-1}$ above warm eddies is not uncommon. Cases where the wind did not increase above the eddies or did not decrease downstream had
\end{abstract}

higher wind speeds and occurred during a cold front associated with intense cyclonic low-pressure systems, suggesting certain synoptic conditions need to be met to allow for the development of wind speed anomalies over warm-core ocean eddies. In many cases, change in wind speed above eddies was masked by a large-scale synoptic wind speed deceleration/acceleration affecting parts of the eddies.

\section{Introduction}

Microwave radiometry and altimetry allow for making observations in the Southern Ocean with unprecedented spatial and temporal resolution. Clouds and water vapour do not inhibit sea surface temperature (SST) estimated by the Advanced Microwave Scanning Radiometer E (AMSR-E) onboard the Aqua satellite. This is a real advantage in the latitudes between 35 to $50^{\circ} \mathrm{S}$ south of Africa where persistent cloud cover previously was a perennial problem in this regard. Furthermore, the merging of measurements by several altimeters flying on the TOPEX/Poseidon satellite, European Research Satellite 2 and Jason-1 satellite allows for a better description of mesoscale ocean features in highly energetic regions (Ducet et al., 2000). In addition, equivalent stabilityneutral instantaneous wind speed estimates from the SeaWinds scatterometer onboard the QuikScat satellite is available from July 1999 (Chelton et al., 2004) to November 2009 at a quarter of a degree resolution along a wide swath.

The latter product, combined with SST estimates from the Tropical Microwave Imager (TMI) onboard the Tropical 
Rainfall Measuring Mission (TRMM), allowed us to demonstrate the impact of mesoscale oceanic features on the overlying atmosphere (Xie, 2004; Chelton and Wentz, 2005). Chelton et al. (2000) and Hashizume et al. (2001) have combined wind stress estimates from QuikScat and TMI SST in the eastern tropical Pacific to study the impact on the atmosphere of tropical instability waves, oceanic features with periods of 20 to 40 days and wavelengths of $1000-2000 \mathrm{~km}$. Chelton et al. (2004) used 4 years of filtered QuikScat data to show a ubiquitous picture of mesoscale ocean-atmosphere interaction linked to SST heterogeneity such as fronts, western boundary currents and tropical instability waves. TMI SST, QuikScat wind speed estimate and in situ observations were also used by Nonaka and Xie (2003) to reveal SST and wind speed covariability over the Kuroshio Extension east of Japan. Frenger et al. (2013) used weekly mean of AMSR-E wind speed, SST, rain rate and liquid cloud water as well as GlobColour cloud fraction to show a coupling between all those parameters for ocean eddies in the Southern Ocean. In general, using satellite estimates many authors found a linear relationship between SST perturbation and wind speed change across SST fronts mostly for SST perturbation from the surrounding ocean ranging from -1 to $1{ }^{\circ} \mathrm{C}$ (Small et al., 2008). However, no linear relationship was found by Park et al. (2006) between change in wind speed and wind stress curl and SST perturbation higher than $1{ }^{\circ} \mathrm{C}$ across Gulf Stream eddies.

Closer to Africa, White and Annis (2003) used low-pass filtered altimetry-derived sea level height, SST and QuikScat meridional wind speed for a period greater than to 1 month and for zonal wavelengths of $400-1200 \mathrm{~km}$ in the Agulhas Current system and they illustrated a coupling between mesoscale eddies and westerly wind. O'Neill et al. (2005) used filtered monthly AMSR-E SST and QuikScat data to show that the wind stress increases and decreases as it goes over warm and cold meanders of the Agulhas Return Current, respectively. Filtering the data on a large domain, they found a linear relationship between SST perturbation and wind stress. Spatial filtering was used to remove the effect of energetic weather disturbances and remove features with wavelengths longer than about $30^{\circ}$ of longitude and $10^{\circ}$ of latitude (Chelton, 2004, O'Neill et al., 2005). Rouault and Lutjeharms (2000) measured high values of latent and sensible heat fluxes above a warm eddy south of the Agulhas Current during the SAAMES (South African Antarctic Marine Ecosystem Study) 3 cruise in June 1993. There was a clear homogeneous increase in wind speed estimate estimated with the European Research Satellite 1 (ERS-1) satellite above this warm eddy, which showed a $6^{\circ} \mathrm{C}$ perturbation compared with surrounding ocean.

Several mechanisms can explain the phenomena that encompass a high range of SST (from 12 to $30^{\circ} \mathrm{C}$ ) and wind speed (from low $\left(3 \mathrm{~m} \mathrm{~s}^{-1}\right)$ to high $\left(15 \mathrm{~m} \mathrm{~s}^{-1}\right)$ wind speed) and they were comprehensively reviewed by Small et al. (2008). It is thought that the increase or decrease of surface wind speed along SST gradient is due to the change in the latent and sensible turbulent heat fluxes and associated change in surface atmospheric stability. Consequently there is a substantial modification of the constant flux layer and of the height and structure of the marine atmospheric boundary layer above the surface layer. According to the numerical study of Samelson et al. (2006) this creates a change in atmospheric conditions leading to the observed wind speed increase or decrease at the surface. Another possible effect is that change in the stability parameter of the constant flux layer at the surface lead to a modification of the logarithm profile that characterises wind speed, temperature and humidity in the surface layer. This increases the downward mixing of momentum (Wallace et al., 1989) leading to the wind speed increase. The change in pressure along SST gradient is also thought to drive secondary circulations (Wai and Stage 1989, Cronin et al., 2003). However, Byrne et al. (2015), a companion paper of Frenger et al. (2013), modelled the effect of ocean eddies in the Southern Ocean on the atmosphere. They found, using a coupled model, that vertical mixing in the atmospheric layer was the main driver of such phenomenon rather than pressure gradient. This is quite similar to results of Spall (2007), who added that background wind speed was an important parameter to determine which of the numerous proposed mechanisms was responsible of the wind increase effect.

Figure 1 shows the mean SST in August 2003 south of Africa done using AMSR-E SST. The Agulhas Current can be seen to follow the eastern coastline of South Africa closely (temperatures exceeding $18^{\circ} \mathrm{C}$ ) and seems to be in the process of shedding an eddy at $37^{\circ} \mathrm{S}, 17^{\circ} \mathrm{E}$. Two well-defined warm eddies with temperatures of about $16-17^{\circ} \mathrm{C}$ are evident at about $40^{\circ} \mathrm{S}, 15^{\circ} \mathrm{E}$ and $42^{\circ} \mathrm{S}, 24^{\circ} \mathrm{E}$. They create a prominent gradient in SST with the surrounding ocean. The meanders of the Agulhas Return Current, object of the study by O'Neill et al. (2005) and Liu et al. (2007), are also evident along $39^{\circ} \mathrm{S}$ from $25^{\circ} \mathrm{E}$ eastwards.

The Agulhas retroflection has an average loop diameter of $340 \mathrm{~km}$ and can be found between 16 and $20^{\circ} \mathrm{E}$ (Lutjeharms and van Ballegooyen, 1988). On average, five anticyclonic eddies are shed each year from the occlusion of the retroflection loop (Schouten et al., 2000) and move in a northwestward direction into the South Atlantic Ocean (Byrne et al., 1995; Schouten et al., 2000). Lutjeharms and Valentine (1988) observed warm eddies with a range of sizes at the termination of the Agulhas retroflection loop shed southward across the Subtropical Convergence into the colder waters of the Southern Ocean that are the object of our study.

Those eddies offer high SST gradients leading to a 5-fold increase of the latent and sensible heat flux (Rouault and Lutjeharms, 2000; Rouault and Lee-Thorp, 1996). Those eddies were chosen because they offer a very distinct SST contrast with surrounding water of up to $6^{\circ} \mathrm{C}$, they move slowly and can be considered almost stationary at the weekly scale. They have a mean radius of about $100 \mathrm{~km}$ and offer a perfect nat- 


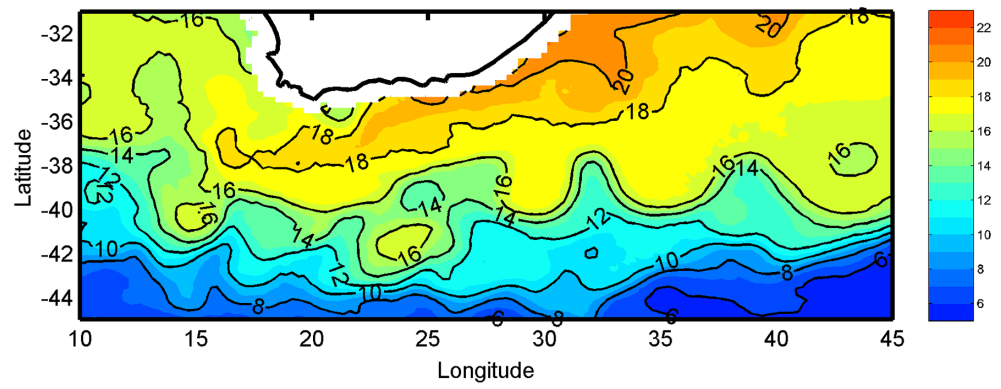

Figure 1. Mean SST $\left({ }^{\circ} \mathrm{C}\right)$ in August 2003 for the region south of Africa, estimated with the Advanced Microwave Scanning Radiometer (AMSR-E) onboard the satellite Aqua. Two warm eddies with temperatures of about $16-17^{\circ} \mathrm{C}$ can be seen centred on $40^{\circ} \mathrm{S}, 15^{\circ} \mathrm{E}$ and $42^{\circ} \mathrm{S}, 24^{\circ} \mathrm{E}$. They create a strong SST gradient with the surrounding ocean. Cold eddies are visible at $38^{\circ} \mathrm{S}, 43^{\circ} \mathrm{E}$ and at $39^{\circ} \mathrm{S}, 25^{\circ} \mathrm{E}$ and an eddy is being shed from the Agulhas Current at $37^{\circ} \mathrm{S}, 17^{\circ} \mathrm{E}$. The meanders of the Agulhas Return Current are also evident from $25^{\circ} \mathrm{E}$ eastward along $39^{\circ} \mathrm{S}$.

ural laboratory for air-sea interaction studies. Due to their high heat content and depth, it takes a few months before they lose their surface expression in temperature. Such an eddy with a $6{ }^{\circ} \mathrm{C}$ contrast with surrounding water was found to modify the ERS-derived wind field at the same time that air-sea interaction measurements were conducted above it during the SAAMES 3 cruise in June 1993 (Rouault and Lutjeharms, 2000).

The objective of our study is to explore the interaction between surface wind speed and warm-core eddies with a clear surface expression (SST perturbation $>1{ }^{\circ} \mathrm{C}$ ) for a variety of large SST perturbations. We want to quantify the effect of the SST perturbation on instantaneous wind speed modification without filtering or averaging the SST or wind fields in space or time. Eddies are identified with a combination of AMSRE SST and altimetry. Twice daily instantaneous gridded wind speed estimates from QuikScat are examined above six warm eddies (Sect. 3) for a period of 2 years and a quantification of the effect of SST perturbation on wind speed increase above those warm eddies and wind decrease downstream is conducted.

\section{Data}

SST was derived from the AMSR-E, launched in 2002 by NASA. It is a passive microwave radiometer with six frequencies that measures brightness temperature at $6.9 \mathrm{GHz}$, for a $90 \%$ complete global ground coverage within a day, with an accuracy of $0.4 \mathrm{~K}$ (Chelton and Wentz, 2005). In this investigation, we use weekly data produced by the Remote Sensing System (RSS) at a resolution of $56 \mathrm{~km}$. We used twice daily equivalent stability-neutral surface instantaneous wind speed and direction estimated by the SeaWinds scatterometer on the QuikScat satellite. It is QuikSCAT Version 3 Level 2B Ocean Wind Vectors available in $25 \mathrm{~km}$ swath grid and produced by Remote Sensing System. Weekly sea level anomalies (SLA) were obtained from Centre national d'études spatiales (CNES). They are given on a one-third of a degree grid (Ducet et al., 2000). They are based on merged observation of the TOPEX/Poseidon, the European Research Satellite 2 (ERS-2) and the Jason-1 altimeters. We also used surface current from GlobCurrent. Surface current was used to make sure that wind data upstream and downstream of the warm-core eddies were not influenced by the eddies' vorticity at their border as the eddies' speed at the border can be on the order of $1 \mathrm{~m} \mathrm{~s}^{-1}$. The GlobCurrent product is an optimal analysis of surface current at two different depth (surface and $15 \mathrm{~m}$ depth) from a number of satellite and in situ observations, it includes 3-hourly geostrophic Ekman and Stokes components of surface current at $1 / 4^{\circ}$ resolution for the period 2002 to 2014 and will be extended to 1993-2015. Its main interest is for the open ocean, away from the coast, where the tidal component is likely to be negligible. GlobCurrent products are freely available from ESA GlobCurrent project portal: globcurrent.org and can be quickly visualised at globcurrent.oceandatalab.com.

\section{Eddy detection}

We looked for eddies with an SLA of $+15 \mathrm{~cm}$ and SST perturbation $>1{ }^{\circ} \mathrm{C}$. The intense mesoscale variability in SLA generated at the Agulhas retroflection and in the Agulhas Return Current make the observation of eddies using satellite altimetry somewhat ambiguous. This is especially true near the shifting or meandering current. However, the combined use of SST and altimetry allows one to identify eddies with less ambiguity than with altimetry alone. The selected eddies (Fig. 2), shed from the Agulhas retroflection and the Agulhas Return Current, were identified in the area of 35 to $45^{\circ} \mathrm{S}$ latitude and 15 to $25^{\circ} \mathrm{E}$ longitude. For most of the eddies, the lifespan does not exceed a couple of months. Most eddies that we are studying stayed quite close to the Agulhas Return Current for a few months and were re-absorbed by the Agulhas retroflection or the Agulhas Return Current. AMSR-E SST was therefore instrumental in corroborating the location of warm eddies and their trajectories. 

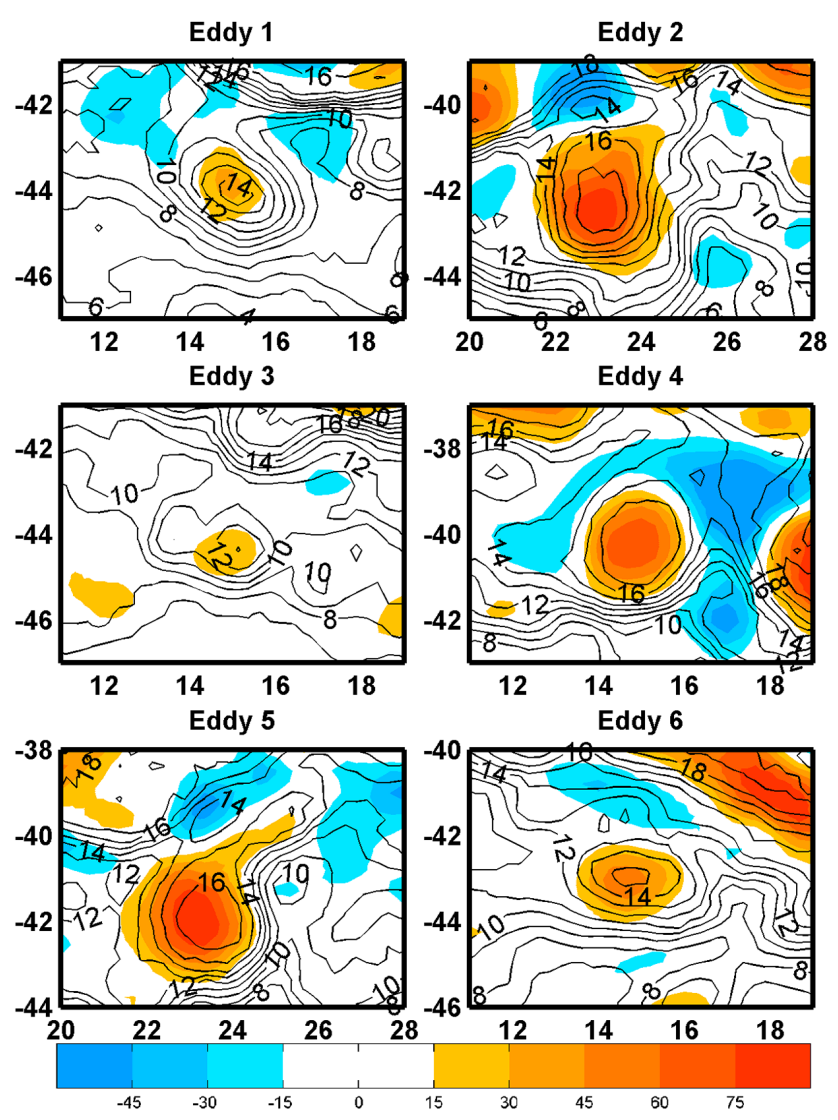

Figure 2. Mean weekly SST $\left({ }^{\circ} \mathrm{C}\right)$ estimated from the AMSR-E and merged seal level anomaly $(\mathrm{cm})$ for the six selected eddies. Times given correspond to weekly means centred at 10 July 2002 for Eddy 1, at 4 September 2002 for Eddy 2, at 19 March 2003 for Eddy 3, at 16 July 2003 for Eddy 4, at 3 September 2003 for Eddy 5 and at 5 May 2004 for Eddy 6. The SLA is in colour and SST contours are at every degree.

Our period of study was July 2002-June 2004 and the geographic domain of the study is defined by Fig. 1. Using SST and altimetry data in this region, we selected warm eddies that had a significantly different thermal expression at the sea surface compared to ambient waters. The first eddy, Eddy 1, was shed off warm water moving westward through the Agulhas retroflection in June 2002 at about $16^{\circ} \mathrm{E}, 41^{\circ} \mathrm{S}$. The eddy had an observed SLA of about $+30 \mathrm{~cm}$ during the first 5 months of its existence. Its diameter was an estimated $130 \mathrm{~km}$. During its first month, the eddy moved southward to $15^{\circ} \mathrm{E}, 44^{\circ} \mathrm{S}$. By mid-July 2002 the surface temperature of the eddy core was over $14^{\circ} \mathrm{C}$, and distinctly warmer than the surrounding water that was 8 to $10^{\circ} \mathrm{C}$. For the analysis of the influence of this eddy on the atmosphere, we focused on the periods when the eddy presented significant SST gradients in July and August 2002. The second eddy, Eddy 2 was shed from the Agulhas Return Current in mid-July 2002 at $24^{\circ} \mathrm{E}, 42^{\circ} \mathrm{S}$. The shedding was not fully complete until the end of August 2002. The maximum SLA observed was about
$+90 \mathrm{~cm}$ with a $4^{\circ} \mathrm{C}$ temperature difference between the edge and the core of the eddy. At the end of October, Eddy 2 seemed to have merged with another eddy. The period of study for this eddy was September to November 2002. Eddy 3 formed as a small eddy at the Agulhas retroflection around mid-January 2003 at $17^{\circ} \mathrm{E}, 43^{\circ} \mathrm{S}$, with a maximum SLA of $20 \mathrm{~cm}$ and a diameter of about $200 \mathrm{~km}$. The eddy moved rapidly southwestward to reach $15^{\circ} \mathrm{E}, 44.5^{\circ} \mathrm{S}$ at the end of March 2003. The temperature difference between the edge of the eddy and its core was about $3{ }^{\circ} \mathrm{C}$. By mid-April 2003, the SST expression of the eddy had disappeared. The period of observation for the third eddy is February and March 2003. The fourth eddy was shed from the retroflection in the first week of July 2003 at $15^{\circ} \mathrm{E}, 40^{\circ} \mathrm{S}$. The SLA at the centre of the eddy was about $65 \mathrm{~cm}$ and the diameter was estimated to be $250 \mathrm{~km}$. The eddy had a maximum SST of over $16^{\circ} \mathrm{C}$ at its core. The surrounding water temperature was between 12 to $14{ }^{\circ} \mathrm{C}$. At the beginning of September 2003, the eddy was re-integrated with the current. Eddy 4 presented a strong gradient of temperature with the surrounding ocean in July and August 2003 and in many respects was similar to the eddy surveyed intensively in June and July 1993 by Rouault and Lutjeharms (2000). The period of observation for this eddy is July and August 2003. Eddy 5 had been shed mid-June 2003 at $24^{\circ} \mathrm{E}, 41^{\circ} \mathrm{S}$ with a maximum SLA of $80 \mathrm{~cm}$. The SST ranged from $12^{\circ} \mathrm{C}$ at the edge to $16^{\circ} \mathrm{C}$ at the centre of the feature. The eddy barely moved during the next 4 months. At the beginning of November 2003, there remained no distinctive SST gradient between the eddy and surrounding waters and it became reattached to the Agulhas retroflection a few weeks later. This eddy had a well-defined SST expression that lasted from July to October 2003. Eddy 6 was shed from the Agulhas retroflection the last week of December 2003. At the end of December 2003, the eddy was about $230 \mathrm{~km}$ in diameter and centred on $16^{\circ} \mathrm{E}, 41^{\circ} \mathrm{S}$, with an observed maximum SLA of $75 \mathrm{~cm}$. It was clearly separated from the Agulhas Current at the end of January 2004 at $15^{\circ} \mathrm{E}, 43^{\circ} \mathrm{S}$ and exhibited a strong gradient with the surrounding ocean. The SST of the eddy was $19^{\circ} \mathrm{C}$ at its core and $12^{\circ} \mathrm{C}$ at the edge. It took about 1 year for the distinct SST expression of the eddy to vanish by which time the temperature of the core had reached the $8^{\circ}$ to $10^{\circ} \mathrm{C}$ of the surrounding water. The eddy SLA was still present at the end of July. Eddy 6 was then located at $12^{\circ} \mathrm{E}, 41^{\circ} \mathrm{S}$. The period of observation for Eddy 6 was from February to June 2004

Although SLA was also used in the merged images, we did not use an SLA threshold to automatise the procedure as SLA contours and SST contours do not match perfectly at all times. When an eddy expression is less than $1{ }^{\circ} \mathrm{C}$ it is actually difficult to precisely spot the eddy with an SST contour only on a daily basis, as the surface expression of the eddies start to vanish, disappear and reappear at times probably due to the effect of strong storms and associated high latent and sensible heat fluxes. 
We considered only SST perturbations $>1{ }^{\circ} \mathrm{C}$. For each case, we extracted SST, SLA, surface current and wind speed at three positions along the wind flow: (a) just before the border (large SST gradient) of the eddy upstream of the centre, (b) in the middle of the eddy and (c) downstream of the eddy border. In order to have robust results, we used a stretch of four points encompassing $100 \mathrm{~km}$ just before and around the eddy, four points at the eddy centre in the direction of the wind and a stretch of four points just after and around the eddy border (high SST gradients) downstream of the eddy centre. SST, wind speed and direction, SLA and surface current for those three locations were then averaged and stored with time and date.

\section{Wind speed acceleration above eddies}

The record represents a total of 22 months of clear-cut, identifiable eddies. We have cases for all seasons with a variety of SST $\left(19\right.$ to $\left.12^{\circ} \mathrm{C}\right)$ and SST perturbations of up to $6{ }^{\circ} \mathrm{C}$. Figure 3 shows four examples of cases showing high wind acceleration above warm eddies and deceleration downstream. We note that the warm Agulhas Current is found to the north of the domain. In the four selected cases, the wind speed increase is larger than $5 \mathrm{~m} \mathrm{~s}^{-1}$ and relatively homogeneous above eddies. However, there are very large wind speed increases of up to $10 \mathrm{~m} \mathrm{~s}^{-1}$ in various locations of those eddies. As will be discussed below, wind differences from the surrounding ocean of about 4 to $7 \mathrm{~m} \mathrm{~s}^{-1}$ are not uncommon above warm eddies. Next, Fig. 4 shows a weekly average of the instantaneous wind speed and SST above the six eddies. Eddies are almost stationary at the weekly timescale. Times given correspond to weekly means centred at 10 July 2002 for Eddy 1, at 4 September 2002 for Eddy 2, at 19 March 2003 for Eddy 3, at 16 July 2003 for Eddy 4, at 3 September 2003 for Eddy 5 and at 5 may 2004 for Eddy 6. Wind is mostly westerly at the weekly scale, a common feature of the "Roaring Forties". Figure 4 shows an average increase in wind speed ranging from 2 to $5 \mathrm{~m} \mathrm{~s}^{-1}$ above all the eddies at the weekly scale. As discussed later, not all instantaneous morning and evening paths display a clear increase above eddies, but eddies have a strong imprint on the wind field when averaging the wind field data for at least a week at the spatial scales of the eddies.

A month of the twice daily QuikScat instantaneous wind speed above eddy 5 in July 2003 averaged for four main wind directions is presented in Fig. 5 as an example. We have separated the data according to four directional quadrants (west, north, east and south) and vector averaged the result. In July 2003, the westerly selection provided 36 cases, the northerly, 18 , the easterly, 1 , and the southerly wind, 6 . Missing data for the easterly case result from rain interference. Wind speed shows clear increases above the eddy for all directions of the wind. The wind strengthening is substantial with an increase from about 10 to $15 \mathrm{~m} \mathrm{~s}^{-1}$ across the eddy. The wind seems also to react rapidly to all features that create a SST gradi-

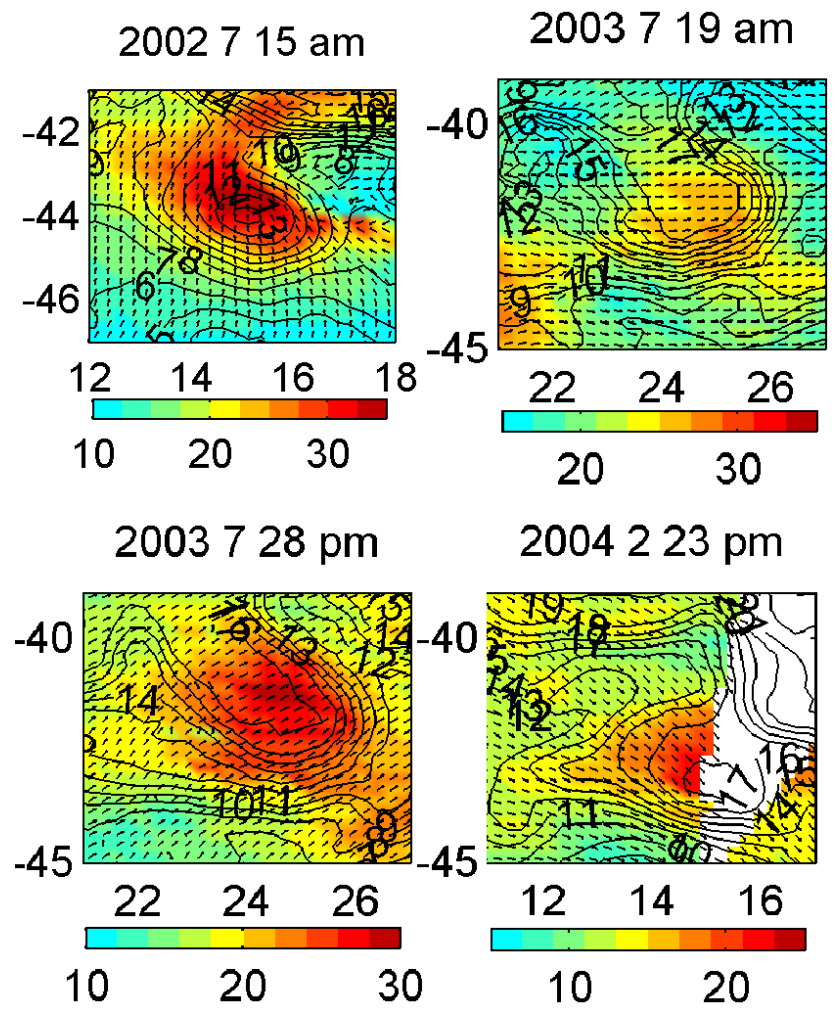

Figure 3. Clockwise from top left, instantaneous estimate of QuikScat wind speed in $\mathrm{ms}^{-1}$ (colour) and directions (arrows) and AMSR microwave sea surface temperature in ${ }^{\circ} \mathrm{C}$ (contours) south of the Agulhas Current system in the "Roaring forties" on the 15 July 2002 (morning path), 19 July 2003 (morning path), 23 February 2004 (evening path) and 28 July 2003 (evening path), showing strong and homogeneous increases and decreases in wind speed collocated with increases and decrease of sea surface temperature.

ent, for instance, the Agulhas retroflection to the north. Air masses coming from the north had already been modified by high latent and sensible heat fluxes above the Agulhas Current (Rouault et al., 2000), yet the wind speed clearly decreases after the Agulhas Current and then increases again above the eddies.

We then systematically plotted the instantaneous wind speed and direction for morning and evening passes from SeaWinds with corresponding interpolated SST and SLA for a period of 2 years and examined those images. Increase in wind speed above warm eddies and decrease downstream were a clear feature for 340 cases, about $50 \%$ of all cases with available data. Wind speed, SST and SLA were also digitally saved in a common latitude-longitude matrix format. We followed the evolution of the six eddies individually and recorded all cases with SST perturbation above $1^{\circ} \mathrm{C}$. We selected 904 situations spread over the lifetime of the eddies. However, $20 \%$ of the cases had no data above eddies mainly because the satellite path sometimes misses the com- 

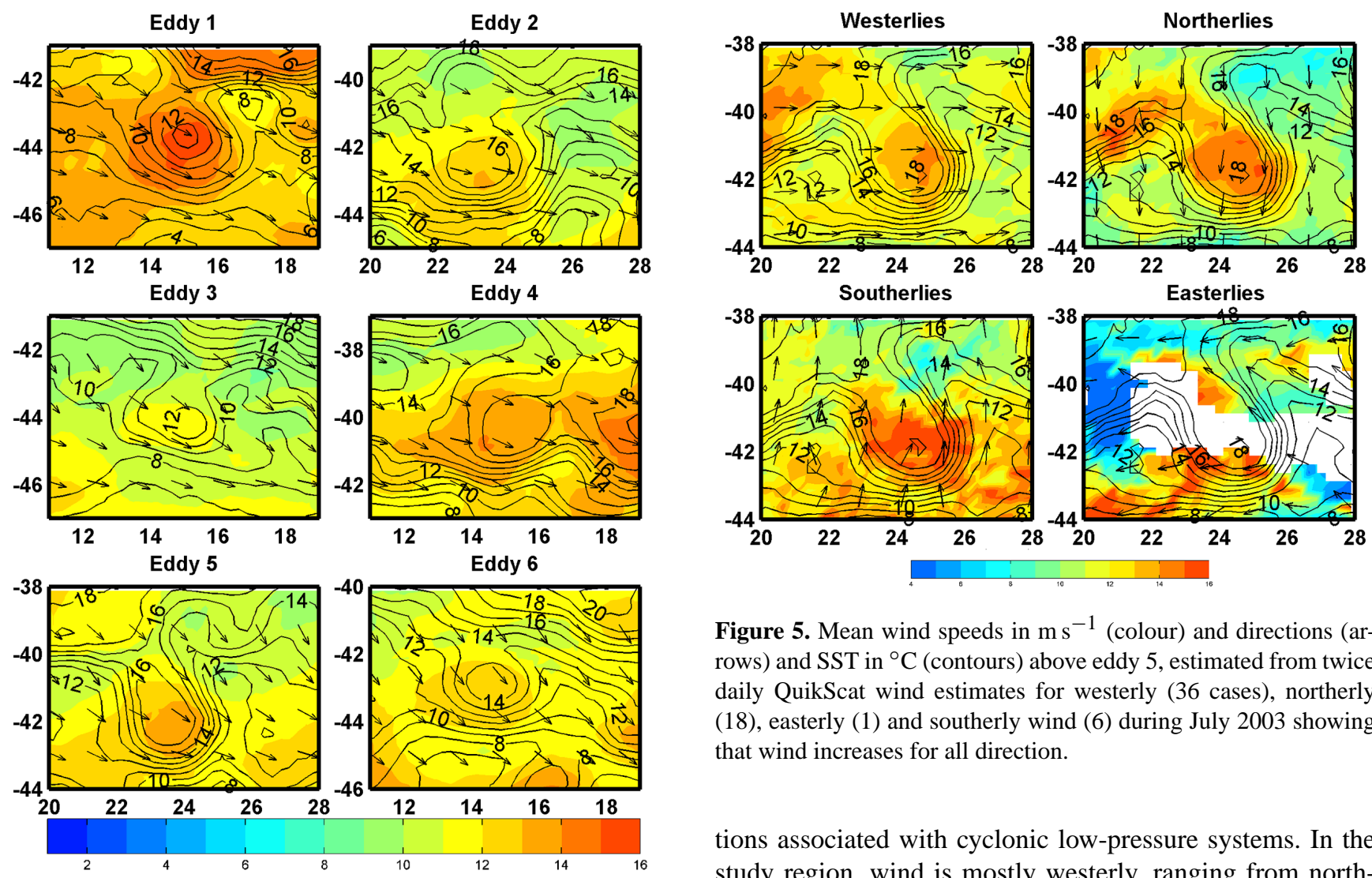

Figure 5. Mean wind speeds in $\mathrm{ms}^{-1}$ (colour) and directions (arrows) and SST in ${ }^{\circ} \mathrm{C}$ (contours) above eddy 5 , estimated from twice daily QuikScat wind estimates for westerly (36 cases), northerly (18), easterly (1) and southerly wind (6) during July 2003 showing that wind increases for all direction.

Figure 4. Mean weekly wind speeds in $\mathrm{m} \mathrm{s}^{-1}$ (colour) and directions (arrows) and SST in ${ }^{\circ} \mathrm{C}$ (contours) above the six eddies. Times given correspond to weekly means centred at 10 July 2002 for Eddy 1, at 4 September 2002 for Eddy 2, at 19 March 2003 for Eddy 3, at 16 July 2003 for Eddy 4, at 3 September 2003 for Eddy 5 and at 5 May 2004 for Eddy 6.

plete eddy or part of it as well as its surrounding water or there is rainfall contamination. This left us with 711 cases.

To quantify the relationship between SST perturbation, wind speed increase above eddies and wind speed decrease downstream, we looked at the statistics of the merged data set of cases that presented a wind speed increase above eddies and a decrease downstream and cases that did not. The eddy SST centres ranged from 19 to $12^{\circ} \mathrm{C}$ with SST perturbation of up to $6^{\circ} \mathrm{C}$ for a mean gradient of $2.5^{\circ} \mathrm{C}$ per $100 \mathrm{~km}$. Altogether, the average SST at the centre of the eddies is $15.9^{\circ} \mathrm{C}$ while average SST at the eddy border is $13.2^{\circ} \mathrm{C}$ upstream and $13.3^{\circ} \mathrm{C}$ downstream. This leads to a mean perturbation of $2.65^{\circ} \mathrm{C}$. Increase in wind speed above warm eddies and decrease downstream were a clear feature for 340 cases, about $50 \%$ of all cases with available data; 180 cases did not show an increase above the warm eddies and 191 cases did not show a decrease downstream of the eddies centre. Histograms, wind roses and wind distribution (Figs. 7-9), as well as average wind speed, indicate that cases that did not show an increase or a decrease happen during frontal condi-

tions associated with cyclonic low-pressure systems. In the study region, wind is mostly westerly, ranging from northwesterly to southwesterly. Gale force northwesterly wind occurs during frontal conditions when cyclonic low-pressure systems and attendant cold fronts impact the region. Gale force southwesterly is typical of post frontal conditions. In between low-pressure systems, isobars are mainly zonal and wind is mainly westerly and slightly lower and weather conditions are more stationary.

For the 340 cases where the wind speed was increasing at the centre and decreasing downstream, the mean wind speed was 11.7 at the entrance, 13.4 at the centre and 11.44 at the exit leading to a mean wind change of about $1.8 \mathrm{~m} \mathrm{~s}^{-1}$ above the eddies. Wind direction for the 340 cases was mostly westerly at the entrance (Fig. 6) and at the exit (not shown) of eddies indicative conditions were quite stationary and a homogeneous wind field. Those conditions often happen in between cold fronts when the isobars become quite zonal in that region. For cases with no increase, the mean wind speed was $12 \mathrm{~m} \mathrm{~s}^{-1}$ at the entrance of eddies, $10.7 \mathrm{~m} \mathrm{~s}^{-1}$ at the centre and $10.1 \mathrm{~m} \mathrm{~s}^{-1}$ at the exit. Wind was mostly southwesterly (Fig. 7) at the entrance and westerly at the exit indicating intense cyclonic circulation. We note that for those cases with no increase at the centre, the wind at the exit is still lower than at the centre indicating a decrease in wind speed as the SST decreases.

For cases with no decrease at the exit, the mean wind speed was $10.45 \mathrm{~m} \mathrm{~s}^{-1}$ at the entrance, $11.18 \mathrm{~m} \mathrm{~s}^{-1}$ at the centre and $12.69 \mathrm{~m} \mathrm{~s}^{-1}$ at the exit. Wind was also mostly southwesterly (Fig. 8) at the entrance and mostly westerly (not 
Joint distribution of speed and direction

\begin{tabular}{|c|c|c|c|c|c|c|c|c|c|c|c|c|c|c|c|c|c|}
\hline & N & NNE & NE & ENE & E & ESE & SE & SSE & S & SSW & SW & WSW & W & WNW & NW & NNW & $\Sigma$ \\
\hline $0-4$ & 0.29 & & & 0.29 & 0.29 & & & & & & & & & 0.29 & 0.29 & & 1.43 \\
\hline $4-8$ & 1.43 & 0.57 & 0.29 & 0.86 & 0.57 & 0.29 & & 0.29 & & 0.57 & 0.29 & 2.00 & 2.00 & 3.14 & 1.43 & 0.86 & 14.57 \\
\hline $8-12$ & 1.43 & 2.57 & 0.86 & 0.57 & & & 0.29 & & 0.57 & 2.00 & 4.00 & 6.86 & 6.86 & 6.86 & 4.86 & 2.86 & 40.57 \\
\hline $12-16$ & 0.86 & 0.29 & & & 0.29 & & & & 0.57 & 2.57 & 1.71 & 5.43 & 5.14 & 6.57 & 7.14 & 2.29 & 32.86 \\
\hline $16-20$ & & & & & 0.29 & & & & 0.29 & & 0.86 & 1.14 & 1.43 & 1.14 & 1.14 & 0.86 & 7.14 \\
\hline $20-24$ & & & & & & & & & & 0.29 & 0.29 & 0.86 & & 0.86 & & & 2.29 \\
\hline $24-28$ & & & & & & & & 0.29 & & & 0.29 & & 0.29 & & 0.29 & & 1.14 \\
\hline $28-32$ & & & & & & & & & & & & & & & & & 0.00 \\
\hline$\Sigma$ & 4.00 & 3.43 & 1.14 & 1.71 & 1.43 & 0.29 & 0.29 & 0.57 & 1.43 & 5.43 & 7.43 & 16.29 & 15.71 & 18.86 & 15.14 & 6.86 & 100.00 \\
\hline
\end{tabular}
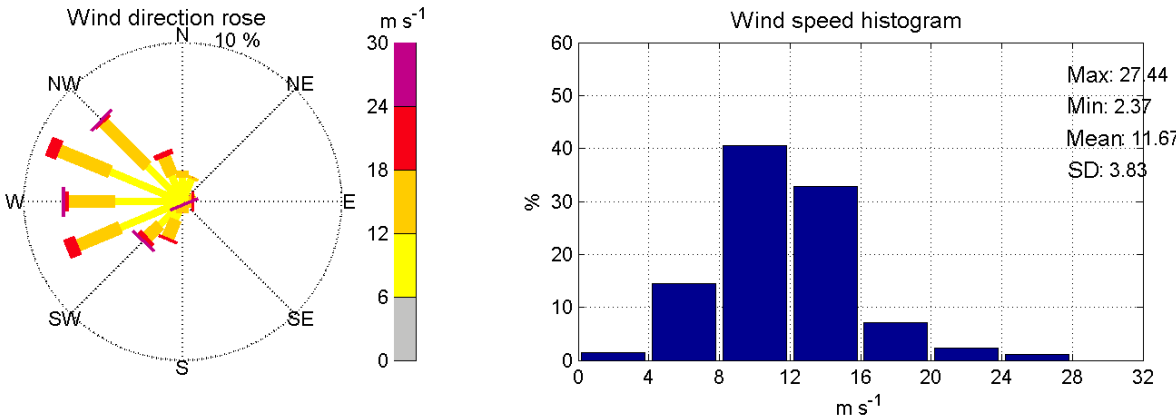

Figure 6. For the 340 cases where there was a wind increase above warm-core eddies and a decrease downstream: distribution in $\%$ and $\mathrm{m} \mathrm{s}^{-1}$ of wind speed and direction (top); wind direction rose (bottom left) and wind speed histogram (bottom right) at the entrance of the eddy upstream.

\begin{tabular}{|c|c|c|c|c|c|c|c|c|c|c|c|c|c|c|c|c|c|}
\hline & N & NNE & NE & ENE & E & ESE & SE & SSE & S & SSW & SW & WSW & W & WNW & NW & NNW & $\Sigma$ \\
\hline $0-4$ & & & & & & & & 0.61 & 0.61 & & & & & & & & 1.21 \\
\hline $4-8$ & 1.21 & & & 1.21 & 0.61 & 0.61 & & 0.61 & 0.61 & 1.21 & 1.21 & 6.67 & 2.42 & 1.82 & 1.21 & 1.21 & 20.61 \\
\hline $8-12$ & 0.61 & 0.61 & 0.61 & & 0.61 & 0.61 & & & & & 4.85 & 8.48 & 7.27 & 3.03 & 1.82 & & 28.48 \\
\hline $12-16$ & & 0.61 & & & & & & & & 1.82 & 7.88 & 9.09 & 7.27 & 4.85 & 1.82 & & 33.33 \\
\hline $16-20$ & & & & & & & & 0.61 & & 0.61 & 0.61 & 2.42 & 0.61 & 1.82 & 1.82 & & 8.48 \\
\hline $20-24$ & & & 0.61 & & & & & & & 0.61 & 1.82 & 1.82 & 0.61 & & & & 5.45 \\
\hline $24-28$ & & & & & & & & & & & 0.61 & 1.21 & & & & & 1.82 \\
\hline $28-32$ & & & & & & & & & & & & & & 0.61 & & & 0.61 \\
\hline$\Sigma$ & 1.82 & 1.21 & 1.21 & 1.21 & 1.21 & 1.21 & 0.00 & 1.82 & 1.21 & 4.24 & 16.97 & 29.70 & 18.18 & 12.12 & 6.67 & 1.21 & 100.00 \\
\hline
\end{tabular}
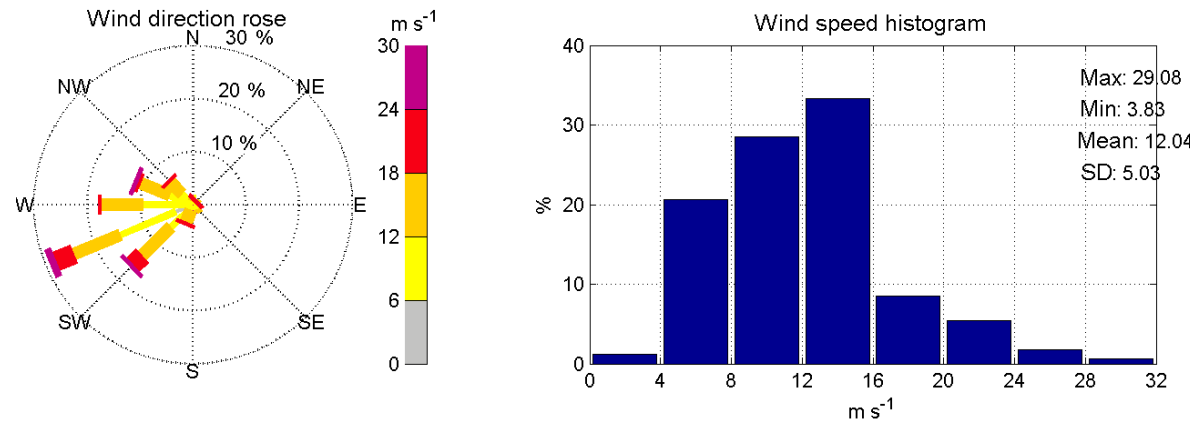

Figure 7. For the 180 cases where there was no wind increase above warm-core eddies: distribution in $\%$ of wind speed and direction and $\mathrm{m} \mathrm{s}^{-1}$ (top); wind direction rose (bottom left) and wind speed histogram (bottom right) at the entrance of the eddy upstream. 
Joint distribution of speed and direction

\begin{tabular}{|c|c|c|c|c|c|c|c|c|c|c|c|c|c|c|c|c|c|}
\hline & N & NNE & NE & ENE & E & ESE & SE & SSE & S & SSW & SW & WSW & W & WNW & NW & NNW & $\Sigma$ \\
\hline $0-4$ & & 1.05 & 0.52 & & 0.52 & & 0.52 & 1.05 & 0.52 & & & & 1.05 & 0.52 & 0.52 & & 6.28 \\
\hline $4-8$ & 1.57 & 3.14 & & 2.09 & & 0.52 & 0.52 & 0.52 & 1.05 & 2.62 & 2.62 & 4.71 & 1.57 & 1.05 & 2.09 & 1.05 & 25.13 \\
\hline $8-12$ & 3.14 & 1.05 & 0.52 & & 1.05 & & 0.52 & 1.05 & 1.05 & 3.14 & 6.81 & 4.19 & 2.62 & 4.19 & 2.09 & 1.57 & 32.98 \\
\hline $12-16$ & & 0.52 & & & & 0.52 & & & & 4.71 & 5.76 & 4.71 & 4.19 & 3.14 & 1.05 & 2.09 & 26.70 \\
\hline $16-20$ & & & & & & & & 0.52 & & & 1.05 & 1.05 & 1.05 & 1.05 & 1.05 & & 5.76 \\
\hline $20-24$ & & & 0.52 & & & & & & & & 0.52 & 1.05 & & & & & 2.09 \\
\hline $24-28$ & & & & & & & & & & & & 1.05 & & & & & 1.05 \\
\hline $28-32$ & & & & & & & & & & & & & & & & & 0.00 \\
\hline$\Sigma$ & 4.71 & 5.76 & 1.57 & 2.09 & 1.57 & 1.05 & 1.57 & 3.14 & 2.62 & 10.47 & 16.75 & 16.75 & 10.47 & 9.95 & 6.81 & 4.71 & 100.00 \\
\hline
\end{tabular}
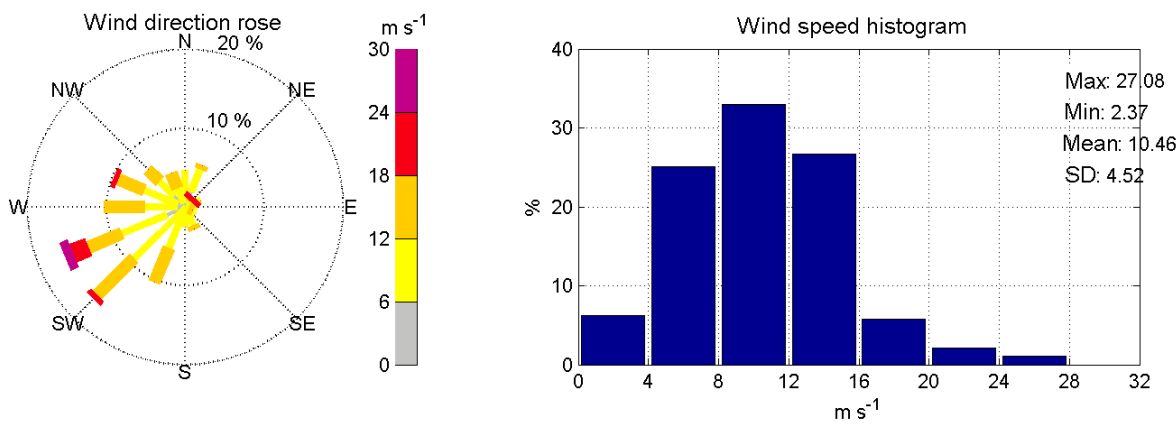

Figure 8. For the 191 cases where there was no wind decrease downstream of warm-core eddies: distribution in $\%$ and $\mathrm{m} \mathrm{s}^{-1}$ of wind speed and direction (top); left: wind direction rose (bottom left) and wind speed histogram (bottom right) at the entrance of the eddy upstream.

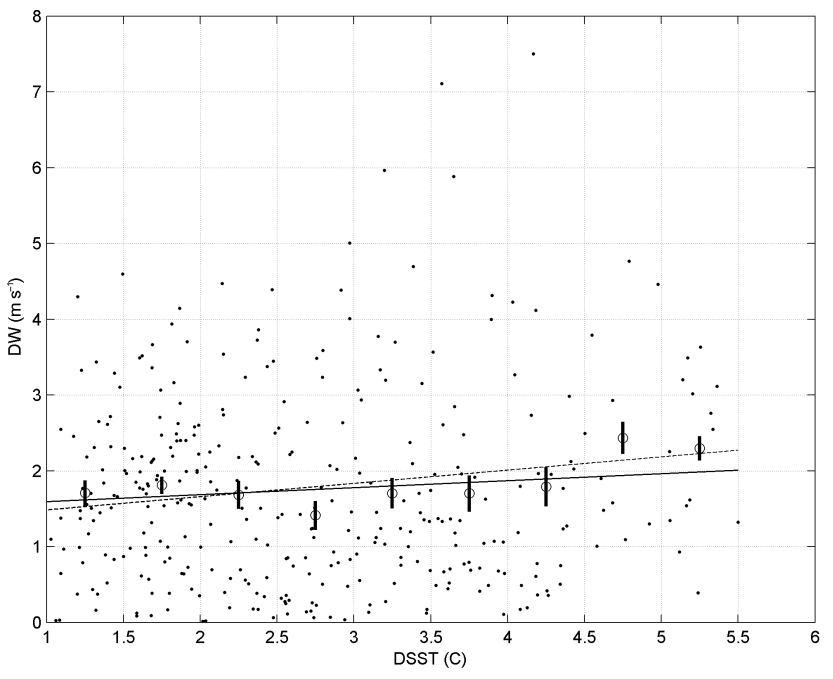

Figure 9. Scatter plot of SST perturbation (DSST) vs. wind speed increase (DW) in $\mathrm{m} \mathrm{s}^{-1}$ relative to wind conditions upstream of the eddy for the 340 cases when the wind increased above warm-core eddies and decreased downstream and for SST perturbation from the surrounding ocean $>1{ }^{\circ} \mathrm{C}$. Solid line is a linear fit. The circle represent the means within each $1^{\circ} \mathrm{C}$ bin and the error bars represent \pm 1 standard deviation of the wind differences within each bin divided by the square root of the number of sample within each bin. The dashed line is a linear fit of the means within the bins. shown) at the exit. Again, wind speed increased from the entrance to the centre of the eddies indicative of an increase of wind speed above warm-core eddies. This suggests that the synoptic conditions could have masked a homogeneous increase in wind speed above warm-core eddies in a number of instances. There was no marked difference in SST between those three categories of wind changes.

For the 340 cases where the wind increased above eddies and decreased downstream, Figs. 9 and 10 present a scatter plot of the instantaneous wind speed increase and decrease (DW) vs. the SST perturbation (DSST). DW is the mean wind speed of the four points at the centre of the eddies minus the average of the four points at the border upstream (Fig. 9) or downstream of the eddies (Fig. 10). The solid line is a linear fit. The circle represents the mean within each $0.5^{\circ} \mathrm{C}$ bin and the error bars are the standard error of the mean, which is \pm 1 standard deviation of the wind differences within each bins divided by the square roots of the number of sample within each bin. The dashed line is a linear fit of the means within the bins. Wind speed changes of up to $7 \mathrm{~m} \mathrm{~s}^{-1}$ are evident in our data set with a great number of cases showing increase larger than $4 \mathrm{~m} \mathrm{~s}^{-1}$. The mean increase was about $1.73 \mathrm{~m} \mathrm{~s}^{-1}$ for a mean wind speed of $11.6 \mathrm{~m} \mathrm{~s}^{-1}$ at the entrance ( $15 \%$ increase), slightly higher than the Park et al. (2006) study of wind speed modification across Gulf Stream eddies, who found an increase of 7.7 to $9.2 \%$ over warm-core eddies. Eddies considered by Park et 


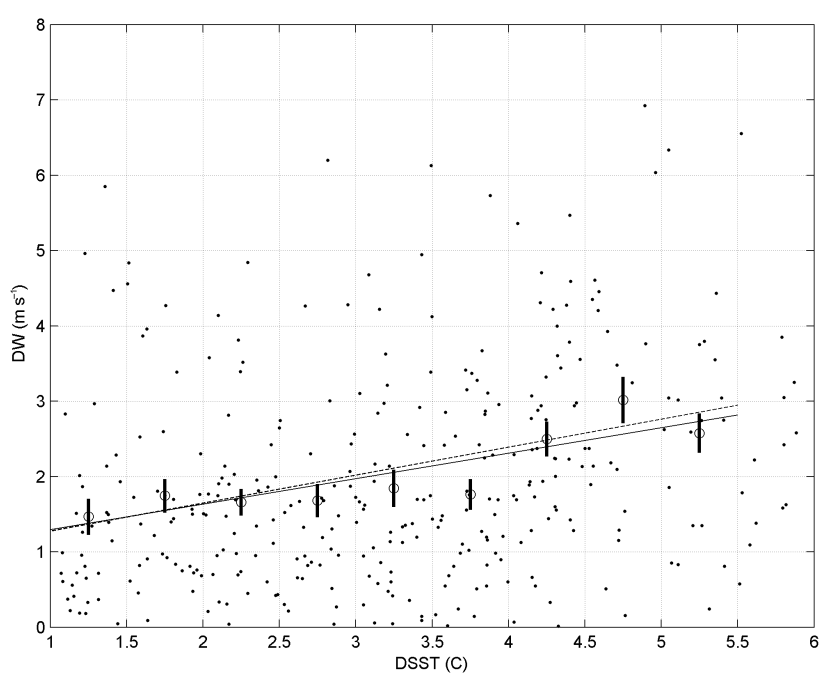

Figure 10. Scatter plot of SST perturbation (DSST) vs. absolute value of wind speed decrease (DW) in $\mathrm{ms}^{-1}$ downstream of the eddy relative to wind conditions over the core of the eddy for cases when the wind increased above eddies and decreased downstream and for SST perturbation from the surrounding ocean $>1{ }^{\circ} \mathrm{C}$. Solid line is a linear fit. The circle represent the means within each $1^{\circ} \mathrm{C}$ bin and the error bars represent \pm 1 standard deviation of the wind differences within each bin divided by the square root of the number of sample within each bin. The dashed line is a linear fit of the means within the bins.

al. (2006) were usually warmer, $19.5^{\circ} \mathrm{C}$ on average. They were 3 to $4{ }^{\circ} \mathrm{C}$ warmer than the surrounding ocean and presented weaker SST perturbations than we are investigating in this study. They had a mean radius of $74 \mathrm{~km}$ and wind speed ranged from 3 to $15 \mathrm{~m} \mathrm{~s}^{-1}$. Wind speed background from our 340 cases ranged between 4 and $16 \mathrm{~m} \mathrm{~s}^{-1}$ (86\% of the cases). In our study, values of wind speed increase and SST perturbation are higher than those of White and Amis (2003), who used filtered data for the same region. They found an average increase of $1.2 \mathrm{~m} \mathrm{~s}^{-1}$ for an average SST perturbation of $0.8^{\circ} \mathrm{C}$. Figure 9 does not show any relation between wind increase DW and SST perturbation DSST but Fig. 10 does show a relationship between wind decrease and SST perturbation. For wind increase (Fig. 9) the correlation between DSST and DW is 0.0725 and $p$ is 0.27 . However, for the decrease in wind speed downstream of eddies centres (Fig. 10), the correlation is highly significant at 0.27 with a $p$ value of 0.0001. For Gulf Stream eddies mentioned above, Park et al. (2006) also show that for strong SST perturbations found in warm or cold core eddies the linear relationship between SST perturbation and wind speed change or wind stress curl change does not hold (Figs. 11, 12 and 16 in Park et al., 2006) when DSST $>1{ }^{\circ} \mathrm{C}$. Our study refines former similar work done in the region. For instance, O’Neil et al. (2005) filtered monthly QuikScat and SST data in their study of wind stress acceleration and deceleration over the Agulhas Return Current, our domain study, and they found a linear relation between SST perturbation and wind speed increase (or decrease). We note that the filtering used by O'Neill et al. (2005) seems to underestimate the high SST gradients experienced in the Agulhas Current. Most of the cases of O'Neil et al. (2005) have SST perturbation between -1 and $1{ }^{\circ} \mathrm{C}$, which is clearly too low (Rouault and LeeThorp, 1996; Lee-Thorp et al., 1999; Rouault and Lutjeharms, 2000; Rouault et al., 1995, 2000). However, in the same region, O'Neill et al. (2012, Fig. 4) show an approximate linear relationship for negative SST anomalies and wind speed decrease for (absolute) SST anomalies larger $1{ }^{\circ} \mathrm{C}$, but for positive SST anomalies larger than $1{ }^{\circ} \mathrm{C}$ the linear relationship in their figure levels off. Another study in the region shows that the linear relationship levels off for gradient greater than to $1{ }^{\circ} \mathrm{C}$ (Supplementary Fig. S4 in Frenger et al., 2013).

To exclude the fact that wind speed increases over eddies merely were not apparent in along-wind direction due to a large-scale wind deceleration, we looked at 924 cases of wind parallel to warm-core eddies and recorded data on each side and in the centre of the eddies, and the conclusions are quite similar as for the 340 cases where the wind increased above eddies and decreased downstream:

a. In all, $20 \%$ of the cases had incomplete wind data.

b. In all, 298 cases (40\%) showed higher wind speeds over the eddy core at each side of the eddies.

c. In all, $87 \%$ of those cases had background wind speed between 4 and $16 \mathrm{~m} \mathrm{~s}^{-1}$ with wind direction equally distributed from the northwesterly to southwesterly wind direction.

d. The mean increase was about $2 \mathrm{~m} \mathrm{~s}^{-1}$; the mean wind speed on the sides was $11 \mathrm{~m} \mathrm{~s}^{-1}$.

e. There was no linear relationship between the SST gradient and wind increase over warm-core eddies (Fig. 11).

f. Cases that showed lower values of wind speed above the center of the warm-core eddies than on either sides also had a southwesterly wind direction.

g. For those latest cases, there was still an increase above the centre when compared to one of the side in many instances.

\section{Discussion}

The aim of the study is to use Agulhas warm-core eddies as a natural laboratory for studying and quantifying surface wind modification above SST fronts. We also want to avoid filtering and to use instantaneous values to be closer to the phenomenon in space and time, and also to use the opportunity given by the great variety of high SST gradient and latent and sensible fluxes experienced above those warm eddies. Finally, since the latent and sensible heat fluxes and the 


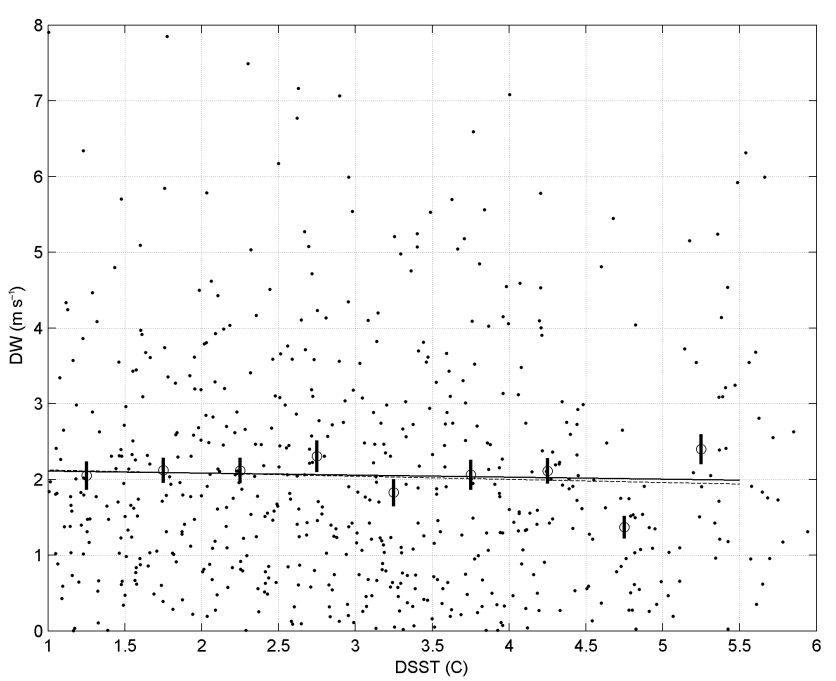

Figure 11. Scatter plot of SST perturbation (DSST) vs. absolute value of wind speed decrease (DW) in $\mathrm{ms}^{-1}$ on each side of the eddy relative to wind conditions over the core of the eddy for cases when the wind was stronger above the core of eddies than on each of their sides, and for SST perturbation from the surrounding ocean $>1{ }^{\circ} \mathrm{C}$ and wind is parallel to the eddies. Solid line is a linear fit. The circle represent the means within each $1^{\circ} \mathrm{C}$ bin and the error bars represent \pm 1 standard deviation of the wind differences within each bin divided by the square root of the number of sample within each bin. The dashed line is a linear fit of the means within the bins.

stability parameters have an impact on the logarithmic profile of wind speed in the surface layer, one could expect to find a relation between SST gradient and wind increase, which we do not find from the cold side of warm-core eddies to the warm side but that we do find from the warm side to the cold side.

A caveat in all those studies of wind increase or decrease above SST fronts is that QuikScat wind speeds were not calibrated for unstable or stable conditions but for neutral conditions. Those unstable conditions occurred above warm Agulhas eddy or Agulhas Current at low wind speed (Rouault and LeeThorp, 1996; Lee-Thorp et al., 1999; Rouault et Lutjeharms, 2000; Rouault et al., 1995, 2000). We recall that the logarithmic profile of wind speed in the boundary layer is a function of the stability parameters. The stability parameter is analogous to the Richardson number, which is the ratio of the work done by the buoyant force to the rate of shear production of turbulent energy. It takes into account both the temperature and moisture dependence of air parcel buoyancy and is affected by the friction velocity. The stability influences the vertical exchange of energy and momentum and thereby the vertical distribution of wind speed, temperature and humidity in the boundary layer. A positive number of the stability means that the conditions are stable and the stratification will act against the turbulence. A Richardson number between 0 and -0.3 means that the stability is neutral. If the stability is less than -0.3 , the conditions are unstable with convective activity: the buoyant force begins to dominate the mixing process. Rouault and Lutjeharms (2000) presented time series of those parameters above a $16{ }^{\circ} \mathrm{C}$ warm-core eddies similar to those studied here. Conditions were neutral or near neutral during the week spend above the eddy during the SAAMES 3 cruises. Only when the wind speed dropped below $5 \mathrm{~m} \mathrm{~s}^{-1}$ did conditions became clearly unstable. Wai and Stage (1989), O'Neill et al. (2005) and Liu et al. (2007) considered the error of QuikScat due to assuming neutral conditions (modification of the logarithmic profile) is small compared to the overall observed increase in wind speed discussed here and in the literature. For instance, the difference at $10 \mathrm{~m}$ between neutral and unstable condition for a $7 \mathrm{~m} \mathrm{~s}^{-1}$ wind speed, relative humidity of $75 \%$, SST of $20^{\circ} \mathrm{C}$ and air temperature of $18^{\circ} \mathrm{C}$ is $0.5 \mathrm{~m} \mathrm{~s}^{-1}$ (Liu et al., 2007, Fig. 1). In our study, we note that because we have quite a strong wind speed here (mean of $11 \mathrm{~m} \mathrm{~s}^{-1}$ ) the conditions are generally near neutral, so this argument (QuikScat wind speed was not calibrated for unstable condition) does not hold to explain the difference between surface wind speed assuming neutral condition only and surface wind speed taking into account unstable condition due to buoyancy. This also probably means that processes involving the whole marine boundary layer as modelled and proposed by Spall (2007) or Byrne et al. (2015) are more likely to be responsible for the increase rather than processes involving the downward transport of momentum in the constant flux layer only at the air-sea interface.

Another potential problem is the resolution of the data used $\left(1 / 4^{\circ}\right)$. For instance in situ measured SST perturbation for an eddy similar to eddy 5 was $6^{\circ} \mathrm{C}$ across $50 \mathrm{~km}$ (Rouault and Lutjeharms, 2000) while our stronger perturbation is $5.5^{\circ} \mathrm{C}$ across $100 \mathrm{~km}$. The relatively low resolution of the AMSR SST could lead to an underestimation of the SST gradient across eddies, but this should not affect the main results presented here due to the sufficiently large size of the eddies

Another caveat was discussed by Grodski et al. (2012), who found an impact of SST on short wind waves and sea roughness was not taken into account in algorithms that are used to estimate wind speed or wind stress with a satellite remote sensing signal. However, the suggested correction would be maximum on the order of $0.2 \mathrm{~m} \mathrm{~s}^{-1}$.

\section{Conclusions}

Modifications to the marine atmospheric boundary layer and ocean-atmosphere interaction across frontal regions were documented during experiments at sea (Sweet et al., 1981; Davidson et al., 1991; Friehe et al., 1991; Rouault et al., 2000, Bourras et al., 2004) and also modelled (Samelson et al., 2006; Bourras et al., 2004; Spall, 2007; Byrne et al., 2015). Satellite remote sensing confirms and extends in space and time the relationship demonstrated during those experiments. Our study provides instantaneous values of wind 
changes above warm-core eddies because we did not filter or average the data. Wind speed increases substantially above warm SST perturbations. This would also increases wind stress and the turbulent fluxes of latent and sensible heat above warm-core eddies. Using microwave remote sensing from satellites provides almost a full global coverage of the Southern Ocean quasi-instantaneously. A combination of merged SLA and microwave SST is a very useful tool for studying the path of eddies and their decay due to intense airsea interaction. Those data could be displayed operationally to provide vessels with early warning and to indicate where there are likely to sustain stronger wind. With increases of more than $4 \mathrm{~m} \mathrm{~s}^{-1}$ in eddies not uncommon, the warning should be taken seriously when sailing in the "Roaring Forties". At last, this study questions the hypothesis that there is a ubiquitous linear relationship between SST increase and wind speed increase for large SST perturbation $>1{ }^{\circ} \mathrm{C}$. Our study raises the question of why there is no linear relationship between SST increase and wind increase above warm eddies, while there is a linear relationship between SST decrease and wind decrease downstream of warm eddies.

Acknowledgements. We thank the reviewers, especially referee no. 3 for his thorough reviews and useful comments that greatly improved the manuscript. Mathieu Rouault wishes to thank ESA GlobCurrent project, ACCESS, NRF, the Nansen-Tutu Center for Marine Environmental Research, IRD and the South African Water Research Commission for financial support. AMSR-E and twice daily wind data were produced by Remote Sensing System, http://www.ssmi.com, and sponsored by NASA's Earth Science Information Partnerships (ESIP): a federation of information sites for Earth Science; and by NASA's TRMM Science Team. Thanks to AVISO, CNES and CLS for making the T/P ERS JASON merged product available. GlobCurrent products are available for free thanks to ESA funding under GlobCurrent DUE project $\mathrm{AO} / 1-7472 / 13 / \mathrm{I}-\mathrm{LG}$.

Edited by: M. Hoppema

\section{References}

Bourras, D., Reverdin, G., Giordani, H., and Caniaux, G.: Response of the atmospheric boundary layer to a mesoscale oceanic eddy in the northeast Atlantic, J. Geophys. Res., 109, D18114, doi:10.1029/2004JD004799, 2004.

Byrne, D. A., Gordon, A. L., and Haxby, W. F.: Agulhas Eddies: a synoptic view using Geosat ERM data, J. Phys. Oceanogr., 25, 902-917, 1995.

Byrne, D., Papritz, L., Frenger, I. , Muennich, M., and Gruber, N.: Atmospheric Response to Mesoscale Sea Surface Temperature Anomalies: Assessment of Mechanisms and Coupling Strength in a High-Resolution Coupled Model over the South Atlantic, J. Atmos. Sci., 72, 1872-1890, doi:10.1175/JAS-D-14-0195.1, 2015.

Chelton, D. B. and Wentz, F. J.: Global high-resolution satellite observations of sea-surface temperature for numerical weather pre- diction and climate research, B. Am. Meteorol. Soc. 86, 10971115, 2005.

Chelton, D. B., Wentz, F. J., Gentemann, C. L., de Szoeke, R. A., and Schlax, M. G.: Satellite microwave SST observations of transequatorial tropical instability waves, Geophys. Res. Lett., 27, 1239-1242, 2000.

Chelton, D. B., Schlax, M. G., Freilich, M. H., and Milliff, R. F.: Satellite measurements reveal persistent small-scale features in ocean winds, Science 303, 978-983, 2004.

Cronin, M. F., Xie, S.-P., and Hashizume, H.: Barometric pressure variations associated with eastern Pacific tropical instability waves. J. Climate, 16, 3050-3057, 2003.

Davidson, K. L., Boyle, P. J., Gautier, C., Hanson, H. P., and Khalsa, S. J. S.: Medium- to large-scale atmospheric variability during the Frontal Air-Sea Interaction Experiment, J. Geophys. Res., 96, 8531-8551, 1991.

Ducet, N., Le Traon, P.-Y., and Reverdin G.: Global high resolution mapping of ocean circulation from TOPEX/Poseidon and ERS1/2, J. Geophys. Res., 105, 19477-19498, 2000.

Frenger, I., Gruber, N. R. Knutti, and Munnich M.: Imprint of Southern Ocean eddies on winds, clouds and rainfall, Nat. Geosci., 6, 608-612, doi:10.1038/ngeo1863, 2013.

Friehe, C. A., Shaw, W. J., Rogers, D. P., Davidson, K. L., Large, W. G., Stage, S. A., Crescenti, G. H., Khalsa, S. J. S., Greenhut, G. $\mathrm{K}$, and Li, F.: Air-sea fluxes and surface layer turbulence around a SST front, J. Geophys. Res., 96, 8593-8609, 1991.

Grodski, S. A., Kudryavtsev, V. N., Bentamy, A., Carton, J. A., and Chapron, B.: Does direct impact of SST on short wind waves matter for scatterometry?, Geophys. Res. Lett., 39, L12602, doi:10.1029/2012GL052091, 2012.

Hashizume, H., Xie, S.-P., T. Liu, W., and K. Takeuchi,: Local and remote atmospheric response to tropical instability waves: A global view from space, J. Geophys. Res, 106, 10173-10185, doi:10.1029/2000JD900684, 2001.

Lee-Thorp, A., Rouault M., and Lutjeharms, J. R. E.:Moisture uptake in the boundary layer above the Agulhas Current: a case study, J. Geophys. Res., 104, 1423-1430, 1999.

Liu, W. T., Xie, X., and Niiler, P. P.: Ocean-Atmosphere Interaction over Agulhas Extension Meanders. J. Climate, 20, 5784-5797, doi:10.1175/2007JCLI1732.1, 2007.

Lutjeharms, J. R. E. and Valentine, H. R.: Eddies at the Sub-Tropical Convergence south of Africa, J. Phys. Oceanogr., 18, 761-774, 1988.

Lutjeharms, J. R. E. and van Ballegooyen, R. C.: The retroflection of the Agulhas Current, J. Phys. Oceanogr., 18, 1570-1583, 1988.

Nonaka, M. and Xie, S.-P.: Covariations of sea surface temperature and wind over the Kuroshio and its extension: Evidence for ocean-to-atmosphere feedback, J. Climate, 16, 1404-1413, 2003.

O’Neill, L. W., Chelton, D. B., Esbensen S. K., and Wentz, F. J.: High-resolution satellite observations of SST modification of the marine atmospheric boundary layer over the Agulhas Return Current, J. Climate, 18, 2706-2723, 2005.

O’Neill, L. W., Chelton, D. B., and Esbensen, S. K. : Covariability of surface wind and stress responses to sea surface temperature fronts, J. Climate, 25, 5916-5942, 2012.

Park, K.-A., Cornillon, P. C., and Codiga, D. L.: Modification of surface winds near ocean fronts: Effects of Gulf Stream rings on 
scatterometer (QuikSCAT, NSCAT) wind observations, J. Geophys. Res., 111, 2156-2002, doi:10.1029/2005JC003016, 2006.

Rouault, M. and Lee-Thorp, A. M.: Fine-time resolution measurements of atmospheric boundary layer properties between Cape Town and Marion Island, S. Afr. J. Marine Sci. 17, 281-296, 1996.

Rouault, M. and Lutjeharms, J. R. E.: Air-sea exchange over an Agulhas eddy at the Subtropical Convergence, The Global Atmosphere and Ocean System, 7, 125-150, 2000.

Rouault, M., Lee-Thorp, A. M., Ansorge, I., and Lutjeharms, J. R. E.: Agulhas Current Air Sea Exchange Experiment, S. Afr. J. Sci., 91, 493-496, 1995.

Rouault, M., Lee-Thorp, A. M., and Lutjeharms, J. R. E.: Observations of the atmospheric boundary layer above the Agulhas Current during alongcurrent winds, J. Phys. Oceanogr., 30, 70-85, 2000.

Samelson, R. M., Skyllingstad, E. D., Chelton, D. B., Esbensen, S. K., O'Neill, , L. W., and Thum, N.: A note on the coupling of wind stress and sea surface temperature, J. Climate, 19, 15571566, 2006.

Schouten, M. W., de Ruijter, W. P. M., van Leeuwen P. J., and Lutjeharms, J. R. E.: Translation, decay and splitting of Agulhas rings in the southeastern Atlantic Ocean, J. Geophys. Res., 105, 21913-21926, doi:10.1029/1999JC000046, 2000.
Small, R. J., DeSzoeke, S. P., Xie, S. P., O’Neill, L., Seo, H., Song, Q., Cornillon, P., Spall, M., and Minobe, S.: Air-sea interaction over ocean fronts and eddies, Dynam. Atmos. Oceans, 45, 274 319, 2008.

Spall, M. A.: Midlatitude wind stress-sea surface temperature coupling in the vicinity of oceanic fronts, J. Climate, 20, 3785-3801, 2007.

Sweet, W., Fett, R., Kerling, J., and LaViolette, P.: Air-sea interaction effects in the lower troposphere across the north wall of the Gulf Stream, Mon. Weather Rev., 109, 1042-1052, 1981.

Wai, M. M. and Stage, S. A.: Dynamical analyses of marine atmospheric boundary layer structure near the Gulf Stream oceanic front, Q. J. Roy. Meteor. Soc., 115, 29-44, 1989.

Wallace, J. M., Mitchell T. P., and Deser, C,: The influence of Sea Surface Temperature on surface wind in the eastern equatorial Pacific: seasonal and interannual variability, J. Climate, 2, 14921499, 1989.

White, W. B. and Annis, J. L.: Coupling of extratropical mesoscale eddies in the ocean to westerly winds in the atmospheric boundary layer, J. Climate, 33, 1095-1107, 2003.

Xie, S.: Satellite observations of cool ocean-atmosphere interaction, B. Am. Meteorol. Soc., 85, 195-208, 2004. 